\title{
Low Wind Speed Wind Tunnel Performance Test: Uniformity Wind Speed in Test Section
}

\author{
Erwin $^{1 *}$, Wahyu Nur Hidayat ${ }^{1}$, Slamet Wiyono ${ }^{2}$ \\ ${ }^{1}$ Renewable Energy Design Laboratory, Engineering Renewable Energy Design Laboratory, Cilegon, Indonesia \\ ${ }^{2}$ Renewable Energy Design Laboratory, Engineering Faculty Universitas Sultan Ageng Tirtayasa Cilegon, Indonesia \\ *Corresponding author. Email: erwin@untirta.ac.id
}

\begin{abstract}
A wind tunnel is a tool used in aerodynamic research to study the effects of air moving past solid objects. A wind tunnel consists of a closed tubular section with the object under test mounted in the middle. This study conducted a test to verify the distributed airflow in the Test Section Wind Tunnel. The wind tunnel has several rooms with their respective functions. Broadly speaking, each chamber has an interrelated function, namely to maintain uniform airflow into the test chamber and out of the test chamber. Thus, the level of turbulence in the test room as long as there is no tested object will be eliminated. The test results get the average percentage of data on the whole field 1 to field 4 , namely field three wind speed one $\mathrm{m} / \mathrm{s}(6 \%)$ the highest and the lowest field four wind speed five $\mathrm{m} / \mathrm{s}(0.4 \%)$. And the average data percentage of field 1 to field 4 (dots) at $1 \mathrm{~m} / \mathrm{s}$ field 1 equal to $9.8 \%$ and at $4 \mathrm{~m} / \mathrm{s}$ field 1 equal to $1.2 \%$.
\end{abstract}

Keywords: Wind Speed, Wind Tunnel, Wind Uniformity, airflow

\section{INTRODUCTION}

Wind tunnels are very important equipment for research on aerodynamics, including the flow of air or gas when passing through a test object such as vehicles, buildings, wind turbines, etc. Wind tunnels are usually used to simulate an airflow condition against a model [1, 2]. Meanwhile, the New and Renewable Energy Laboratory of Mechanical Engineering, Faculty of Engineering, Untirta, does not yet have a wind tunnel testing facility. This research is focused on testing the performance of low wind speed wind tunnels on measuring wind speed distribution in the Test Section (where the test object) is the wind tunnel. The research objective to be achieved by the author is to verify the distributed airflow in the Test Section Wind Tunnel. This is relevant to one of the studies related to this research, namely the evaluation of the scale model of the hybrid vertical axis wind turbine windmill and the testing of the scale model in the wind tunnel with the aim of testing using a wind tunnel on wake recovery [1].

Aerodynamics is taken from the words Aero and Dynamics, which can be interpreted as air and changes in motion. A change in the motion of an object due to air resistance when the object is moving at high speed. A wind tunnel is a tool used in aerodynamic research to study the effects of air moving past solid objects. A wind tunnel consists of a closed tubular section with the object under test mounted in the middle [3]. A powerful fan system moves air past the object.

\section{METHODS}

This research uses the design method. The research was conducted at the Department of Mechanical Engineering, Sultan Ageng Tirtayasa University, and the time of this research lasted approximately seven months, from October 2020 to April 2021 [4].

The stages are as follows:

1. Literature Study

This stage is carried out to seek additional information related to testing the performance of low wind speed wind tunnels.

2. Test ParametersAt this stage, information is added from the wind tunnel design per section, namely honeycomb, contraction, test section, and diffuser [5].

3. Design of wind tunnel experiment

This stage shows how to collect data in the test room (test section).

4. Experiment 
This stage is carried out by setting up experiments before taking data. After that, data collection or testing is carried out in the test section.

5. Analysis

This stage conducts research or analysis of the test data that has been obtained.

6. Conclusion

This is the last stage of the overall test, where the conclusion contains the things that are considered the main result.

\subsection{Test Procedure}

- Start

- Install the wind speed sensor (testo 405i) at the first predetermined point.

- Setting the $\mathrm{Hz}$ (inverter) according to what will be used.

- Start the wind speed reading on the smartphone connected to the testo 405 i.

- Setting 1 minute each time the data is taken per 2 seconds reading the data read by the sensor.

- After 1 minute is obtained, save the data file by sending the data to the user's email.

- Download files from an email that is already connected to a laptop (testo 405i).

- Analysis of data files.

- Finished.

\subsection{Experiment Setup}

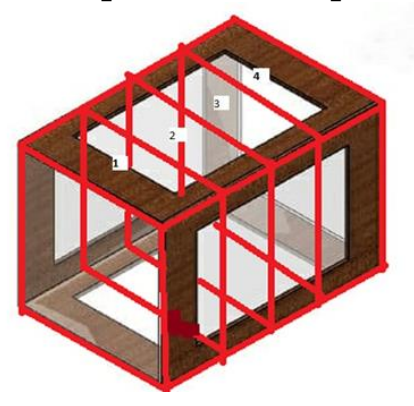

12

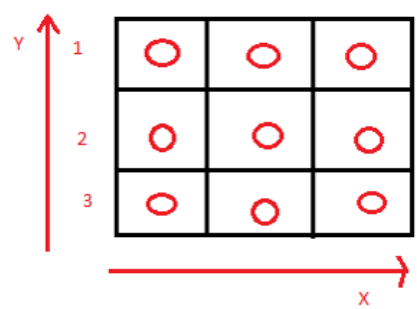

Figure 1. Test Filed
The tested field and the field to be taken wind speed data distributed at each predetermined point, in each field 1, 2, 3 and 4. In each field 1, 2, 3 and 4, there are 9 points each in the one field[6]. Each point will take 30 data within $1 \mathrm{~min} / 2$ seconds.

Table 1. Naming each point in one plane

\begin{tabular}{|c|c|c|}
\hline$X$ & $Y$ & $Z$ \\
\hline 1 & 1 & - \\
\hline 2 & 1 & - \\
\hline 3 & 1 & - \\
\hline 1 & 2 & - \\
\hline 2 & 2 & - \\
\hline 3 & 2 & - \\
\hline 1 & 3 & - \\
\hline 2 & 3 & - \\
\hline 3 & 3 & - \\
\hline
\end{tabular}

Note: The $z$ value is the wind speed value obtained after testing data collection

\section{RESULTS AND DISCUSSION}

The results of the test data from five layer in test section are that a graph is obtained as follows:

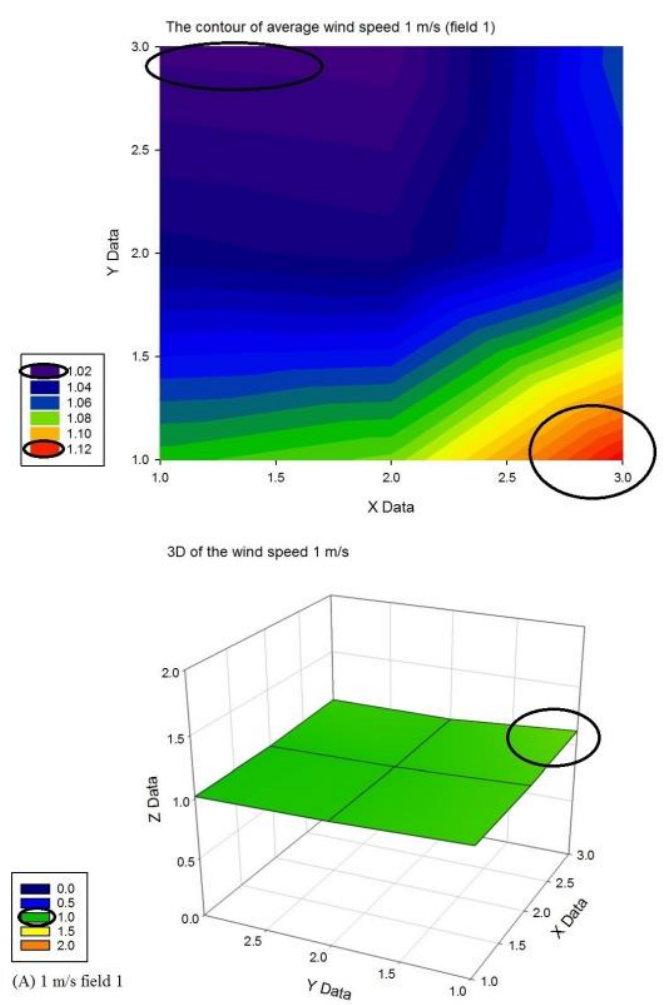



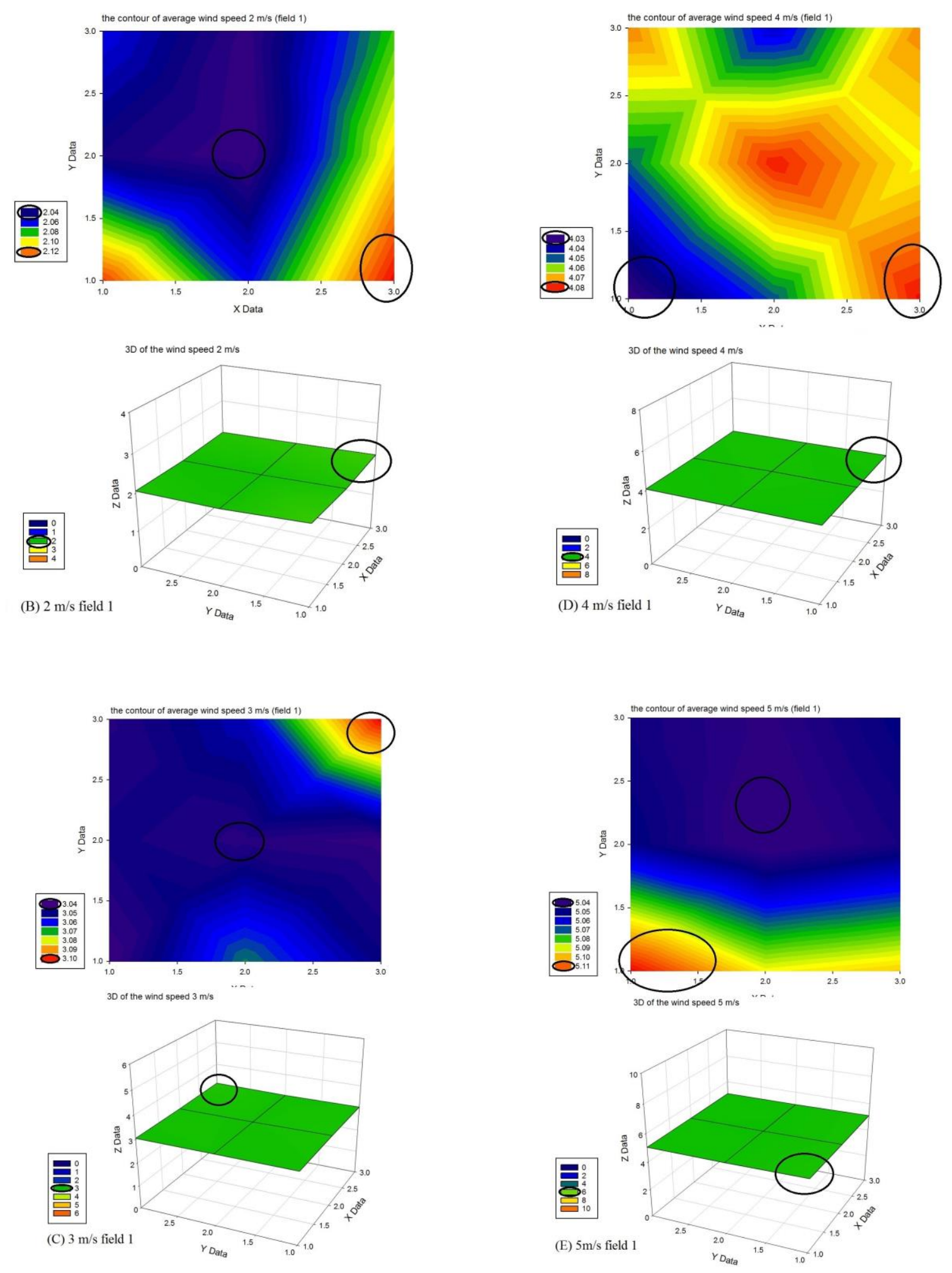

Figure 2. Uniformity result in different wind speed 
Test results with wind speeds of $1 \mathrm{~m} / \mathrm{s}$ to $5 \mathrm{~m} / \mathrm{s}$ with testing in field 1. Using a Thermo anemome-ter testo $405 \mathrm{i}$ measuring instrument $[8,9]$. The results of the image above show an uneven distribution of wind speed. The red part shows an increase in chang-es in wind speed, and the green part shows within the uniformity limit of the flow in the field, the blue col-our shows a decrease in changes in wind speed.

Table 2. Results of the average data percentage of field 1 with wind speeds of $1 \mathrm{~m} / \mathrm{s}$ to $5 \mathrm{~m} / \mathrm{s}$

\begin{tabular}{|l|l|l|l|l|l|}
\hline & $1 \mathrm{~m} / \mathrm{s}$ & $2 \mathrm{~m} / \mathrm{s}$ & $3 \mathrm{~m} / \mathrm{s}$ & $4 \mathrm{~m} / \mathrm{s}$ & $5 \mathrm{~m} / \mathrm{s}$ \\
\hline Field 1 & $9.8 \%$ & $3.9 \%$ & $1.9 \%$ & $1.2 \%$ & $1.3 \%$ \\
\hline
\end{tabular}

Table 3. Results of the overall average data percentage in field 1 to field 4

\begin{tabular}{|c|c|c|c|c|c|}
\hline & $1 \mathrm{~m} / \mathrm{s}$ & $2 \mathrm{~m} / \mathrm{s}$ & $3 \mathrm{~m} / \mathrm{s}$ & $4 \mathrm{~m} / \mathrm{s}$ & $5 \mathrm{~m} / \mathrm{s}$ \\
\hline Field 1 & $\begin{array}{c}1.04 \\
(4 \%)\end{array}$ & $\begin{array}{c}2.06 \\
(3 \%)\end{array}$ & $\begin{array}{c}3.05 \\
(1.6 \\
\%)\end{array}$ & $\begin{array}{c}4.05 \\
(1.25 \%)\end{array}$ & $\begin{array}{c}5.05 \\
(1 \%)\end{array}$ \\
\hline Field 2 & 1.05 & 2.05 & 3.04 & 4.05 & 5.04 \\
& $(5 \%)$ & $\begin{array}{c}(2.5 \% \\
(1.3\end{array}$ & $(1.25 \%)$ & $(0.8 \%)$ \\
& & ) & $\%)$ & & \\
\hline Field 3 & 1.06 & 2.06 & 3.03 & 4.05 & 5.04 \\
& $(6 \%)$ & $(3 \%)$ & $(1 \%)$ & $(1.25 \%)$ & $(0.8 \%)$ \\
\hline Field 4 & 1.05 & 2.04 & 3.03 & 4.02 & 5.02 \\
& $(5 \%)$ & $(2 \%)$ & $(1 \%)$ & $(0.5 \%)$ & $(0.4 \%)$ \\
\hline
\end{tabular}

Based on table 2. The results of the average data percentage of fields with wind speeds of $1 \mathrm{~m} / \mathrm{s}$ to $5 \mathrm{~m} / \mathrm{s}$ obtained the optimum percentage of $9.8 \%$ from the range of $1-10 \%$. This is in accordance with one of the statistics of one of the studies related to this study, namely the analysis of subsonic wind tunnels with variations in the shape of rectangles and octagons in the test section with a deviation of $10 \%$, which is close to the results of the author's research.[10].

The results of this study verify the wind speed distribution in the test section, the test is carried out on the test field only. So that from this research the value of wind speed deviation is obtained.

\section{CONCLUSION}

This test experiment was carried out to verify the uniformity of the flow distribution in the test section, and the results of data collection showed that the flow distribution in the test section was uniform, the percentage of wind speed in the entire field. In field three the wind speed is one $\mathrm{m} / \mathrm{s}(6 \%)$, the highest and the lowest is in plane four the wind speed is five $\mathrm{m} / \mathrm{s}(0.4 \%)$ is still within the tolerance limit for uniformity of flow.

\section{REFERENCES}

[1] E. Erwin, T. P. Soemardi, A. Surjosatyo, Y. S. Nugroho, K. Nugraha, and R. D. Andayani 2019 Analysis of near wake recovery scale model vawt hybrid wind turbin in wind tunnel IOP Conference Series: Materials Science and Engineering 508 no. 1, p. 012068: IOP Publishing

[2] S. U. J. P. P. I. Handayani 2014 Pengembangan dan analisa keseragaman aliran terowongan angin tipe terbuka sebagai sarana pengujian aerodinamika pp. A 309-A 314

[3] M. Haryanti and M. J. T. J. T. E. Awaludin 2019 Rancangan sensor kecepatan angin pada wind tunnel 21 no. 1 pp. 44-49

[4] Y. F. Sipayung, I. Ismail, and E. A. Pane 2019 Analisis sistem PIV pada terowongan angin rangkaian terbuka in Seminar Nasional Teknik Mesin 9 no. 1, pp. 264-272

[5] A. A. Kharisma and A. J. P. Sutanto 2020 Analisa aerodinamis distribusi tekanan open circuit low subsonic wind tunnel terhadap pengaruh variasi peletakan screen mesh 22 no. 2, pp. 59-68

[6] N. Yuniarsih and W. J. J. I. Rossbandrio 2015 Pengembangan terowongan angin kecepatan rendah (low speed wind tunnel) untuk tujuan edukatif di Politeknik Negeri Batam 7 no. 1, pp. 19-22

[7] A. A. Wicaksana and M. J. J. C. Kabib 2020 Analisa turbulensi honeycomb pada bentuk penampang melingkar pada wind tunnel subsonic 3 no. 1

[8] P. A. Hendrayanto Optimization design of open circuit wind tunnel suction type

[9] E. Purwanto and E. Achdi 2019 Pengujian dan analisa distribusi kecepatan angin pada terowongan angin tipe terbuka Fakultas Teknik Unpas

[10] D. Rhakasywi, A. Suwandi, and A. Fadhli 2018 Analysis of subsonic wind tunnel with variation shape rectangular and octagonal on test section in IOP Conference Series: Materials Science and Engineering 308 no. 1, p. 012036: IOP Publishing 